Jurnal InFestasi

Vol. 12, No.1, Juni 2016

Hal. $20-35$

\title{
DETERMINAN KINERJA KEUANGAN PERUSAHAAN MANUFAKTUR DI INDONESIA; EKSPLORASI INTELLECTUAL CAPITAL DAN CORPORATE GOVERNANCE
}

\author{
Dewa Ayu Oki Asta Rini \\ Akram \\ Lilik Handajani \\ Fakultas Ekonomi, Universitas Mataram, NTB, Indonesia \\ oki.astarini22@gmail.com
}

\begin{abstract}
ABSTRAK
The aim of research is to know the intellectual capital, corporate governance effect and company's characteristic toward financial archievment at manufacture company by using partial lest square (PLS). The research was apllied in 38 manufacture company (28,78 \% from 132 companies) by using secondary data in front of financial and annual report from 2011 to 2013. The result indicated that intellectual capital has positive effect toward financial achievment, which indicated that the company hasi seriousness to give value by using high VAICTM and increase the intangible asset thorugh MBIC. Corporate governance has so significant effect toward financial achievment, that indicate the how level of suitability in applying corporate governance. Practice toward the entirely principle of OECD (2004). Corporate governance pratice that the refer to OECD (2004) principle is still dominated by the role of stakeholder in corporate governance. The transparancy and responsibility of committe. In the future, the company must give more right of shareholder's and the equitable treatment to shareholder

Keywords : Intellectual capital, corporate governance, fiancial perfomance
\end{abstract}

ABSTRAK
Penelitian ini bertujuan untuk menguji dan menemukan bukti empiris mengenai pengaruh intellectual capital dan corporate governance terhadap kinerja keuangan pada perusahaan manufaktur dengan menggunakan alat analisis Partial Least Square (PLS). Pengujian dilakukan pada 38 perusahaan manufaktur $(28,78 \%$ dari 132 perusahaan manufaktur) dengan menggunakann data sekunder berupa laporan keuangan dan laporan tahunan dengan dari tahun 2011 sampai dengan tahun 2013. Hasil penelitan ini menunjukkan bahwa intellectual capital berpengaruh signifikan postif terhadap kinerja keuangan, yang mengindikasikan perusahaan memiliki keseriusan untuk menghasilkan nilai tambah dengan metode VAICTM dan meningkatkan nilai intangible asset dengan metode MBIC. Corporate governance tidak berpengaruh signifikan terhadap kinerja keuangan, yang mengindikasikan rendahnya tingkat keselarasan pelaksanaan praktik corporate governance terhadap keseluruhan prinsip OECD (2004). Praktik corporate governance yang merujuk pada prinsip OECD (2004) masih di dominasi oleh peran stakeholder dalam corporate governance, keterbukaan dan transparansi serta tanggung jawab dewan. Kedepan perusahaan harus lebih meningkatkan perhatian dan kepatuhan terhadap prinsip hak pemegang saham dan kesetaraan perlakukan terhadap pemegang saham.

Keywords : intellectual capital, corporate governance, kinerja keuangan.

\section{PENDAHULUAN}

Perkembangan dunia bisnis saat ini menghadapkan perusahaan pada persaingan yang semakin ketat. Perusahaan dengan kinerja keuangan yang baik akan lebih mudah menghadapi persaingan bisnis. Kinerja keuangan perusahaan tercermin dalam laporan keuangan yang meliputi laporan posisi keuangan, laporan laba rugi komperhensif, laporan arus kas, laporan 
perubahan ekuitas, dan catatan atas laporan keuangan (PSAK 1 revisi 2010). Laporan keuangan menjelaskan kinerja entitas satu periode dalam laporan laba rugi komperhensif. Informasi tentang kinerja diperlukan untuk menilai perubahan potensial sumber daya ekonomi yang mungkin dikendalikan di masa depan seperti modal intellektual atau Intellectual Capital (IC).

Pada akhir 1980-an, akademisi dan praktisi mulai meningkatkan perhatian tentang praktik IC. Dengan alasan, bahwa jika aturan akuntansi tidak beradaptasi dengan meningkatnya kebutuhan untuk memberikan informasi yang relevan tentang investasi di IC, akuntansi akan kehilangan relevansinya. Salah satu efek yang muncul dari potensi kerugian terkait relevansi informasi akuntansi adalah meningkatnya gap atau kesenjangan antara nilai pasar (market value) dan nilai buku (book value) ekuitas selama tahun 1980-an dan 1990an. Hal ini tidak dapat dijelaskan dengan tingkat pertumbuhan laba kontemporer, namun sebagian investor mulai menghargai meningkatnya tingkat investasi di IC sebagai sumber potensi profitabilitas masa depan (Nakamura 1999).

Di Indonesia, fenomena IC mulai berkembang terutama setelah munculnya PSAK 19 (revisi 2000) yang membahas aktiva tidak berwujud. Munculnya PSAK 19 (revisi 2000) secara tidak langsung memberi perhatian khusus pada IC. PSAK 19 terbaru (revisi 2010) menyebutkan bahwa aset tak berwujud diakui jika dan hanya jika: pertama, kemungkinan besar perusahaan akan memperoleh manfaat ekonomis masa depan dari aset tersebut. Kedua, biaya perolehan aset tersebut dapat diukur secara handal. Persyaratan ini sesungguhnya sulit dipenuhi, sehingga sampai saat ini IC belum dapat dilaporkan dalam laporan keuangan perusahaan. Kondisi itu tentu menyulitkan bagi calon investor untuk dapat melakukan analisis dan penilaian atas prospek perusahaan di masa yang akan datang berdasarkan potensi IC yang dimiliki.

Calon investor menilai IC memiliki potensi untuk mendukung kinerja keuangan perusahaan menjadi lebih baik sehingga akan berdampak bagi pada prospek perusahaan ke depanya. Hubungan IC dengan kinerja keuangan berlandaskan teori Resource Based View (RBV). Menurut resource based view perusahaan dapat memperoleh keunggulan kompetitif dan kinerja keuangan yang baik dengan cara memiliki, menguasai, dan memanfaatkan aset-aset strategis yang penting yang memungkinkan perusahaan untuk memahami dan mengimplementasikan strategi guna meningkatkan efisiensi dan efektivitas perusahaan (Barney, 1991; Wernerfelt, 1984). Bertolak belakang dengan meningkatnya pengakuan IC dalam mendorong nilai dan keunggulan kompetitif perusahaan, pengukuran yang tepat terhadap IC perusahaan belum dapat ditetapkan (Ullumet al., 2008). Beberapa pendekatan yang telah banyak digunakan oleh sejumlah penelitian yaitu VAICTM oleh Pulic (1998, 1999,2000) dan pendekatan pasar MBIC oleh Edvinson dan Malone (1997).

Ketepatan pengukuran IC perusahaan yang belum ditetapkan tidak menjadikan halangan untuk dilakukanya penelitian mengenai IC. Sejumlah penelitian telah dilakukan untuk meneliti hubungan IC terhadap kinerja keuangan. Chen et al.,(2005), Tan et al.,(2007), Soetedjo dan Mursida (2008), Ullum et al.,(2008), Gamayuni (2010), Fajarini dan Firmansyah (2012), Yunita (2012), Kumalasari (2013), Prastya (2014) dalam penelitianya menunjukan adanya pengaruh IC terhadap kinerja keuangan. Hasil yang berbeda disimpulkan oleh Firer dan Williams (2003) serta Subagyo dan Lahagu (2012) yang tidak menemukan adanya pengaruh IC terhadap kinerja keuangan.

Eksplorasi determinan kinerja keuangan selanjutnya adalah praktik tata kelola perusahaan atau corporate governance. Good Corporate Governance (CCG) semakin gencar dilakukan semenjak munculnya skandal akuntansi seperti kasus Enron, dan Worldcom yang melibatkan akuntan. Di Indonesia juga telah tercatat beberapa kasus yang melibatkan persoalan laporan keuangan seperti PT. Lippo dan PT. Kimia Farma yang berawal dari terdeteksi adanya manipulasi (Boediono, 2005). 
Munculnyan skandal akuntansi tersebut menjadikan penerapan GCG pada setiap perusahaan tidak hanya wajib namun juga telah menjadi kebutuhan bagi setiap perusahaan. Praktik corporate governance yang merujuk pada GCG akan berperan efektif untuk mengarahkan perusahaan mendapatkan kinerja keuangan yang lebih baik. Hubungan corporate governance dengan kinerja keuangan berlandaskan pada agency theory oleh Jensen dan Meckling (1976) yang menjelaskan hubungan kontrak kerja antara pemilik (principal) dengan manajer (agent) yang cenderung memiliki informasi lebih banyak (asimetri informasi). Untuk menghindari terjadinya asimetri informasi diperlukan corporate governance yang dapat memberikan perlindungan efektif kepada principal yaitu para pemegang saham dan pihak kreditur sehingga dapat meyakinkan pemegang saham dan kreditur untuk memperoleh kembali investasinya dengan wajar dan bernilai tinggi, hal tersebut akan menjadi daya tarik yang dimiliki perusahaan untuk mendapatkan investasi yang lebih banyak (Susilawati dan Soetjipta, 2013).

Di bidang Pasar Modal saat ini masih terdapat beberapa prinsip yang belum diterapkan pada corporate governance, berdasarkan survey CLSA, Mc Kinsey, Standar \& Poors mengenai penerapan GCG, posisi Indonesia masih berada di kelompok terbawah (bottom quartile). Komite Nasional Kebijakan Governance (KNKG), memiliki target meningkatkan posisi Indonesia pada top quartile dalam internasional rating mengenai penerapan corporate governance. Dalam rangka mengembangkan penerapan corporate governance yang baik di industri pasar modal dan sekaligus mendukung target yang telah ditetapkan di atas, maka perbaikan terhadap corporate governance terus dilakukan. Sebagai acuan praktik sistem corporate governance yang baik, KNKG mengacu pada prinsip yang diterbitkan oleh Organisation for Economic Co-operation and Development (Bapepam, 2006).

Perbaikan terhadap praktik corporate governance akan memberikan manfaat bagi perusahaan untuk menghasilkan kinerja keuangan yang lebih baik. Sejumlah penelitian yang telah menguji hubungan corporate governance dengan kinerja keuangan yaitu Kllaper dan Love (2002), Cornet et al.,(2005), Utari dan Fachrurzzaman (2013), Prastya (2014) dalam penelitianya mengungkapkan adanya pengaruh corporate governance terhadap kinerja keuangan. Namun penelitian dengan hasil yang berbeda ditunjukan melalui penelitian oleh Supatmi (2007), Arifani (2013), Windah dan Andono (2013) yang tidak ditemukanya pengaruh corporate governance terhadap kinerja keuangan.

Determinan kinerja keuangan yaitu intellectual capital dan corporate governance telah diuji oleh sejumlah penelitian yang beberapa diantaranya menunjukkan hasil yang berbeda menjadi daya tarik tersendiri untuk dilakukan penelitian kembali. Penelitian ini merupakan pengembangan dari penelitian yang dilakukan oleh Prastya (2014) yang berjudul "Pengaruh Modal Intellektual dan Tata Kelola Perusahaan terhadap Kinerja Keuangan". Prastya (2014) menggunakan alat analisis regresi berganda, namun penelitian kali ini menggunakan metode struktural dengan analisis partial least square yang dianggap mampu merefleksikan variabelvariabel dalam bentuk indikator. Prastya (2014) hanya mengeksplorasi satu indikator dalam setiap variabel penelitianya sedangkan penelitian ini menggunakan lebih dari satu indikator. Penelitianya ini mengukur kinerja keuangan sebagai variabel dependen menggunakan ROA (return on asset), CAR (current asset ratio) dan ATR (asset turnnover ratio) yang juga digunakan oleh penelitian sebelumnya yaitu Gamayuni (2010). Intellectual capital sebagai variabel independen diukur menggunakan VAIC ${ }^{\mathrm{TM}}$ oleh Pulic (1999)dan MBIC(market based intellectual capital) oleh Edvinsion dan Malone (1997). Corporate governance sebagai variabel independen diukur dengan pendekatan content analysis untuk mendapatkan informasi mengenai corporate governance yang merujuk pada GCG berdasarkan prinsip OECD (2004). 
Hubungan Intellectual Capital dengan Kinerja Keuangan

RBV menjelaskan perusahaan dapat memperoleh keunggulan kompetitif dan kinerja keuangan yang baik dengan cara memanfaatkan aset strategis yang dimiliki sehingga memungkinkan perusahaan untuk mengimplementasikan strategi guna meningkatkan efisiensi dan efektivitas perusahaan (Barney,1991; Wernerfelt, 1984). IC merupakan sumber daya yang mampu menggerakkan kinerja organisasi dan penciptaan nilai (Bontis, 1998). Perusahaan yang tidak yakin terhadap potensi IC dan tidak serius untuk mengelola dan mengembangkanya tidak akan berpengaruh terhadap kinerja keuangan.

Penelitian Williams (2003) serta Subagyo dan Lahagu (2012) tidak menemukan adanya pengaruh IC terhadap kinerja keuangan. Hasil penelitian yang berbeda ditunjukkan oleh Tan et al.,(2007), Chen et al.,(2005), Ullum et al.,(2008), Soetedjo dan Mursida (2008), Gamayuni (2010), Fajarini dan Firmansyah (2012), Yunita (2012), Kumalasari (2013), Prastya (2014), yang menunjukan adanya pengaruh IC terhadap kinerja keungan. Perusahaan yang yakin terhadap potensi IC akan memaksimalkan perhatian dan pengelolan IC sehingga akan menghasilkan kinerja keuangan yang semakin optimal. Berdasarkan uraian diatas, maka hipotesis pertama adalah sebagai berikut : Intellectual Capital berpengaruh positif terhadap kinerja keuangan.

\section{Hubungan Corporate Governance Dengan Kinerja Keuangan}

Agency theory menjelaskan adanya hubungan kontrak antara agent dan principal yang dimana agent menerima mandat untuk mengelola perusahaan dari principal, yang memungkinkan terjadinya benturan kepentingan keduanya (Jensen dan Meckling, 1976). Hal tersebut akan berakibat pada berkurangya kepercayaan investor yang berimbas pada menurunya jumlah investasi yang diperoleh perusahaan. Sistem corporate governance yang baik mampu mengatasi dan memberikan perlindungan efektif kepada para pemegang saham dan pihak kreditur dari kemungkinan adanya benturan kepentingan, sehingga bisa meyakinkan investor untuk memperoleh kembali investasinya dengan wajar dan bernilai tinggi (Susilawati dan Soetjipta, 2013).

Saat ini sejumlah perusahaan di pasar modal masih belum secara penuh menerapkan praktik corporate guernance yang merujuk pada prinsip GCG, sehingga corporate governance tidak dapat berperan efektif bagi kinerja keuangan perusahaan. Sesuai dengan penelitiaan Arifani (2013), Windah dan Andono (2013) dan Supatmi (2007) yang menunjukan corporate governance tidak berpengaruh terhadap kinerja keuangan. Corporate governance dapat berperan efektif pada perusahaan apabila memenuhi standar praktik corporate governance yang merujuk pada prinsipprinsip GCG seperti prinsip OECD (2004) yaitu memuat mengenai hak pemegang saham, kesetaraan perlakuan terhadap pemegang saham, peran pemangku kepentingan, pengungkapan dan transparansi, serta pertanggungjawaban dewan (Handajani et al., 2014). Dengan semakin efektifnya peran corporate governance akan meningkatkan kepercayaan dan jumlah investasi yang diperoleh dari investor sehingga perusahaan dapat menghasilkan kinerja keuangan yang optimal. Corporate governance berpengaruh terhadap kinerja keuangan dibuktikan oleh penelitian Kllaper dan Love (2002), Cornet et al.,(2005), Supatmi (2007), Arifani (2013), Windah dan Andono (2013), Utari dan Fachrurzzaman (2013), Prastya (2014). Berdasarkan uraian diatas, maka hipotesis kedua dalam penelitian ini adalah sebagai berikut: Corporate Governance Berpengaruh Positif Terhadap Kinerja Keuangan Perusahaan.

\section{METODE PENELITIAN}

\section{Populasi data Penelitian}

Populasi dalam penelitian ini adalah perusahan manufaktur yang terdaftar di Bursa Efek Indonesia periode 2011-2013. Metode pengambilan sampel dalam penelitian ini menggunakan metode purposive sampling. Jumlah perusahaan 
yang berhasil memenuhi kriteria sampel sebanyak 38 perusahaan.

\section{Variabel Penelitan dan Pengukuran}

Kinerja keuangan adalah ukuran prestasi yang dapat dicapai oleh perusahaan yang mencerminkan kondisi kesehatan keuangan dari suatu perusahaan dalam periode tertentu. (Munawir, 2002:24). Kinerja keuangan diukur menggunakan rasio keuangan sebagai berikut:

\section{Current Ratio}

Rasio Lancar $=$ Aktiva Lancar $:$ Kewajiban Lancar. (Brealey et all , 2007: 78)

\section{Asset Turnover Ratio}

Rasio Perputaran Total Aktiva = Penjualan : Rata-Rata Total Aktiva. (Van\&Wachowicz, 2005:224).

Return On Invesment / On Asset.

Tingkat Pengembalian Investasi Dari Pendapatan Operasi = Laba Bersih Setelah Pajak : Total Aktiva. (Van \& Wachowicz, 2005:224).

Intellectual Capital (IC) merupakan sumber daya, kemampuan dan kompetensi, yang menggerakkan kinerja organisasi dan penciptaan nilai (Bontis, 1998:67). IC dalam penelitian ini diukur menggunakan metode VAIC ${ }^{\text {TM }}$ dan MBIC. Formulasi perhitungan VAIC ${ }^{\mathrm{TM}}$ oleh Pullic (1998) adalah sebagai berikut:

Tahap 1 : Rasio untuk mengukur VA

$$
\mathrm{VA}=\text { OUT-IN }
$$

Tahap 2 :Rasio yang menunjukkan kontribusi yang dibuat oleh setiap unit dari CE terhadap VA organisasi:

$$
\mathrm{VACA}=\mathrm{VA} / \mathrm{CE}
$$

Tahap 3: Rasio yang menunjukkan kontribusi yang dibuat oleh setiap rupiah yang diinvestasikan dalam HC terhadap VA organisasi:

$$
\mathrm{VAHU}=\mathrm{VA} / \mathrm{HC}
$$

Tahap 4: Rasio ini mengukur jumlah SC yang dibutuhkan untuk menghasilkan 1 rupiah dari VA dan merupakan indikasi bagaimana keberhasilan SC dalam penciptaan nilai:

$$
\mathrm{STVA}=\mathrm{SC} / \mathrm{VA}
$$

Tahap 5 : Rasio untuk mengukur value added intellectual coefficient sebagai business performance indicator (mengindikasikan kemampuan intelektual organisasi) :

\section{$\mathrm{VAIC}^{\mathrm{TM}=} \mathrm{VACA}+\mathrm{VAHU}+\mathrm{STVA}$}

\section{Keterangan :}

OUT : output (total penjualan dan pendapatan lain-lain)

IN :input (beban dan biaya-biaya selain beban karyawan)

VA :value added (selisih input dan output)

HC :human capital(beban karyawan)

$\mathrm{CE}$ :capital employed (jumlah ekuitas dan laba bersih)

SC :structural capital(selisih VA dengan human capital)

VACA : value added capital employed

VAHU :value added human capital

STVA :structural capital value added

VAICTM:value added intellectual coefficient

Formulasi Perhitung Market Based IC-MBIC oleh Edvinsion dan Malone (1997) adalah sebagai berikut :

Tahap 1: Rasio untuk mengukur BVNA yaitu dimana selisih antara nilai buku asset dan nilai buku liabilitas yang tercantum dalam laporan keuangan cukup signifikan hal ini menandakan bahwa terdapat aset tersembunyi yang tidak tercantum dalam laporan keuangan yang disebut sebagai intangible assets.

$\mathrm{BVNA}=\mathrm{BVOA}-\mathrm{BVOL}$

Tahap 2: Rasio untuk mengukur selisih antara nilai buku dengan nilai pasar.Nilai pasar perusahaan mencerminkan persepsi pasar yang berasal dari investor, kreditor, maupun stakeholder lain terhadap kondisi perusahaan yang diukur dengan mengalikan outstanding share perusahaan dengan harga saham pada tahun terakhir. Selisih nilai pasar dan nilai buku yang cukup signifikan menandakan bahwa terdapat aset tersembunyi yang tidak tercantum dalam laporan keuangan yang disebut sebagai intangible assets. Agar hasil perhitungan tidak terlalu besar dan tidak terlalu jauh 
satuanya dengan indikator yang lain maka digunakan log natural dari CMV dan BVNA yang kemudian di formulasikan sebagai berikut :

MBIC $=\log$ natural CMV-log natural BVNA

Keterangan :

BVNA :book value net asset.

BVOL : book value of liabilities.

BVOA: book value of asset

$\mathrm{CMV}$ :corporate market value.

MBIC : market based intellectual capital.

Corporate governance merupakan sistem yang mengendalikan perusahaan dengan mengatur hubungan hak dan kewajiban antara stakeholder dan shareholder (Tjager dkk., 2003:25).
Pendekatan content analysis digunakan untuk mendapatkan Informasi corporate governance dalam annual report melalui form-orientated dan meanings occurrence (Moloi, 2008). Penilaian praktik corporate governance menurut OECD (2004) memuat mengenai hak pemegang saham, kesetaraan perlakuanterhadap pemegang saham, peran pemangku kepentingan, pengungkapan dan transparansi, serta pertanggungjawaban dewan.

\section{Analisis dan Data}

Penelitian ini melibatkan tiga variabel eksogen (intellectual capital, corporate governance, karakteristik perusahaan) dan satu variabel endogen (kinerja keuangan). Model pengukuran dan struktural adalah sebagai berikut :

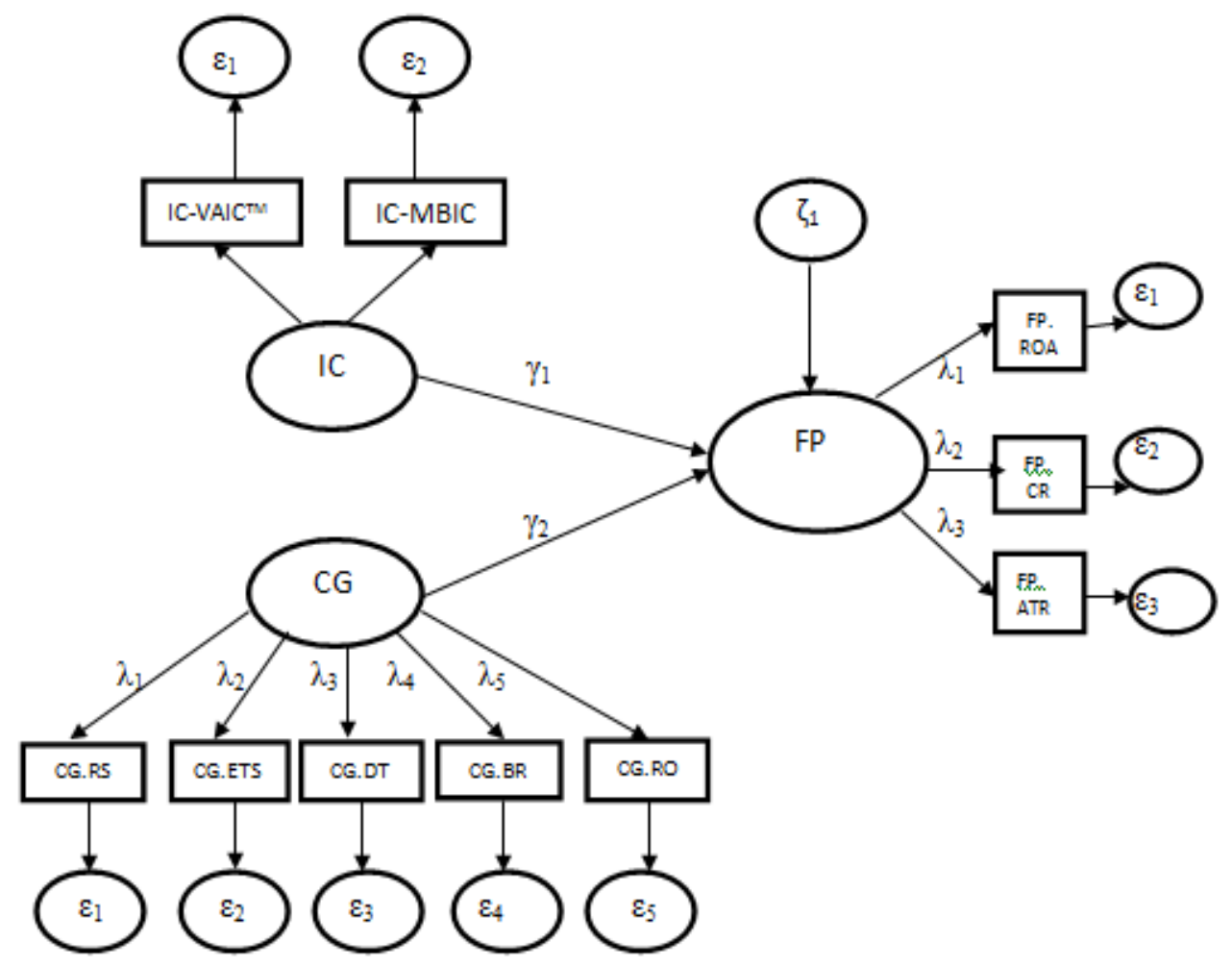

Gambar 1. Model Struktural dan Pengukuran dengan PLS 
Model diuji dengan persamaan sebagai berikut :

$$
\begin{array}{ll}
\mathrm{IC} & =\lambda_{1} \mathrm{VAIC}^{\mathrm{TM}}+\lambda_{2} \mathrm{MBIC}+\varepsilon_{\mathrm{i}} \\
\mathrm{CG} & =
\end{array}
$$

$\lambda_{1} \mathrm{RS}+\lambda_{2} \mathrm{ET}+\lambda_{3} \mathrm{RO}+\lambda_{4} \mathrm{DT}+\lambda_{5} \mathrm{BR}+\varepsilon_{\mathrm{i}}$

Model persamaan struktural diuji dengan persamaan sebagai berikut :

$$
\mathrm{FP}=\gamma_{1} \mathrm{ROA}+\gamma_{2} \mathrm{CR}+\gamma_{3} \mathrm{ATR}+\zeta_{1}
$$

Keterangan :

$\lambda$ = Lamda, Matrik loading indikator reflektif,

$\varepsilon=$ Epsilon, galat pengukuran indikator reflektif,

$\mathrm{\gamma}=$ Gamma, koefisien pengaruh variabel eksogen,

$\zeta=$ Zeta, galat model Intellectual

Capital(IC), direfleksikan dengan indikator :

IC. VAIC ${ }^{\mathrm{TM}}=$ Vaule Added Intellectual Coefficient,

IC. MBIC =Intellektual Capital

Market Based

Corporate Governance ( CG) , direfleksikan dengan indikator

CG.RS = Right of Shareholder,

CG.ET = Equitable Treatment of Shareholder;

CG.RO $=$ Role of Stakeholder in Corporate

Governance,

CG.DT = Disclosure and Transparency,

CG.BR $=$ Board Responsibility.

PEMBAHASAN

\section{Statistik Deskriptif}

Statistik deskriptif memberikan gambaran atau deskriptif suatu data yang dilihat dari nilai rata-rata (mean), standar deviasi, maksimum, dan minimum, dari masing-masing variabel. Mean digunakan untuk mengetahui ratarata data yang bersangkutan. Standar deviasi digunakan untuk mengetahui seberapa besar data yang bersangkutan bervariasi dari rata-rata. Nilai maksimum digunakan untuk mengetahui jumlah terbesar data yang bersangkutan. Nilai minimum digunakan untuk mengetahui jumlah terkecil data yang bersangkutan bervariasi dari rata-rata.

Variabel yang digunakan meliputi variabel eksogen yaitu intellectual capital (IC) dengan 2 indikator, corporate governance (CG) dengan 5 indikator dan karakteristik perusahaan atau firm characteric (FC) dengan 3 indikator. Sementara variabel endogen yaitu kinerja keuangan atau financial perfomance (FP) terdiri dari 3 indikator. Hasil pengujian statistik deskriptif dapat dilihat pada tabel 1 berikut ini :

Tabel 1.Hasil Statistik Deskriptif

\begin{tabular}{lrrrrr}
\hline & N & Minimum & Maximum & \multicolumn{1}{c}{ Mean } & \multicolumn{1}{c}{ Std. Deviation } \\
\hline FP.CR & 114 &, 4000 & 9,3400 & 2,315175 & 1,6506482 \\
FP.ATR & 114 &, 2200 & 2,9600 & 1,244737 &, 5218605 \\
FP.ROA & 114 & 0,0000 &, 4000 &, 105965 &, 0872969 \\
IC.VAICTM & 114 & $-1,8600$ & 20,3100 & 5,389912 & 3,4590749 \\
IC.MBIC & 114 & $-3,0100$ & 3,9900 &, 336754 & 1,4018827 \\
CG.RS & 114 &, 13 & 1,00 &, 5004 &, 23650 \\
CG.ETS & 114 &, 1100 & 1,0000 &, 360965 &, 2424140 \\
CG.RO & 114 &, 25 & 1,00 &, 7741 &, 21547 \\
CG.DT & 114 &, 5000 & 1,0000 &, 837719 &, 1218808 \\
CG.BR & 114 &, 3300 & 1,0000 &, 717719 &, 1510848 \\
Valid N & 114 & & & & \\
(listwise) & & & & & \\
\hline
\end{tabular}

Indikator current ratio (CR) menunjukan nilai minimum 0,4 dan nilai maximum 9,34. Nilai mean sebesar 2,31 menunjukan rata-rata current ratio perusahaan manufaktur perusahaan manufaktur tahun 2011 sampai dengan tahun 2013 dalam kategori rendah. Hal ini mengindikasikan perusahaan manufaktur telah mampu mengelola aktiva lancarnya dengan efisien dan 
optimal sehingga tidak mengalami kesulitan dalam melunasi utang jangka pendeknya. Standar deviasi current rasio sebesar 1,65 yang nilainya semakin mengecil dari nilai mean menunjukan data sampel yang semakin homogen.

Indikator asset turn over perusahaan manufaktur menunjukan nilai minimum 0,22 dan nilai maxsimum sebesar 2,95. Nilai mean sebesar 1,24 menunjukan rata-rata ATR perusahaan manufaktur tahun 2011 sampai dengan tahun 2013 dalam kategori cukup baik. Hal ini mengindikasikan perusahaan manufaktur dari tahun 2011 sampai dengan tahun 2013 memiliki perputaran aktiva yang cukup baik dan efisien dalam menghasilkan penjualan sehingga dapat meningkatkan perolehan laba. Standar deviasi asset turn over sebesar 0,52 yang nilainya semakin mengecil dari nilai mean menunjukan data sampel yang semakin homogen.

Indikator ROA (return on asset) menunjukkan nilai minimum 0 dan nilai maximum 0,4. Nilai mean sebesar 0,1 menunjukkan rata-rata ROA perusahaan manufaktur perusahaan manufaktur tahun 2011 sampai dengan tahun 2013 dalam kategori yang cukup baik. Hal ini mengindikasikan perusahaan manufaktur mampu menghasilkan laba dari total aktiva yang digunakan untuk beroperasi dan memiliki peluang untuk meningkatkan pertumbuhan. Standar deviasi ROA sebesar 0,08 yang nilainya semakin mengecil dari nilai mean menunjukan data sampel yang semakin homogen.

Indikator VAIC ${ }^{\mathrm{TM}}$ menunjukan nilai minimum 1,86 dan nilai maximum 20,31. Nilai mean sebesar nilai 53,89, menunjukkan rata-rata VAICTM perusahaan manufaktur tahun 2011 sampai dengan tahun 2013 dalam kategori cukup baik. Hal ini mengindikasikan perusahaan manufaktur kurang efisien dalam memanfatkan modal perusahan yaitu human capital, structural capital dan capital employed untuk meningkatkan nilai tambah intellektual bagi perusahaan. Standar deviasi VAICTM sebesar 3,45 yang nilainya semakin mengecil dari nilai mean menunjukan data sampel yang semakin homogen.
Indikator MBIC menunjukkan nilai minimum -3 dan nilai maximum 3,98. Nilai meansebesar 0,33menunjukkan rata-rata MBIC perusahaan manufaktur tahun 2011 sampai dengan tahun 2013 dalam kategori rendah. Hal ini mengindikasikan hidden value yang dihasilkan dari selisih antara nilai pasar dengan nilai buku tidak terlalu besar dikarenakan penilaian pasar oleh investor terhadap keberadaan intanggible asset yang rendah. Standar deviasi MBIC sebesar 1,40 yang nilainya semakin membesar dari nilai mean menunjukan data sampel yang semakin bervariasi.

Indikator hak pemegang saham atau right of shareholder (RS) menunjukan nilai minimum $12,5 \%$ dan nilai maximum 100\%. Nilai meansebesar $49,78 \%$ menunjukan rata-rata RS perusahaan manufaktur tahun 2011 sampai dengan tahun 2013dalam kategori yang rendah. Hal ini mengindikasikan masih banyak perusahaan yang belum mengungkapkan mengenai pemberian hak khusus baik itu keuntungan ataupun informasi kepada pemegang saham. Standar deviasi RS sebesar 0,23 yang nilainya semakin mengecil dari nilai mean menunjukan data sampel yang semakin homogen.

Indikator kesetaraan perlakuaan terhadap pemegang saham atau equitable treatment of shareholder (ETS) menunjukkan nilai minimum $11 \%$ dan nilai maksimum 100\%. Nilai mean sebesar 36,2\%menunjukan rata-rata ETS perusahaan manufaktur tahun 2011 sampai dengan tahun 2013 dalam kategori yang rendah. Hal ini mengindikasikan perlindungan perusahaan kepada investor dari kemungkinan terjadinya usaha yang merugikan kepentingan investor belum diberikan secara optimal. Standar deviasi 0,24 yang nilainya semakin mengecil dari nilai mean menunjukan data sampel yang semakin homogen.

Indikator peran stakeholders dalam corporate governance atau role of stakeholder in corporate governance (RO) nilai minimum $25 \%$ dan nilai maximum $100 \%$. Nilai mean sebesar $77 \%$ menunjukan rata-rata $\mathrm{RO}$ perusahaan manufaktur tahun 2011 sampai dengan tahun 2013 dalam kategori yang cukup tinggi. Hal ini mengindikasikan bahwa 
kerja sama yang terjalin dengan baik antara pemangku kepentingan dengan perusahaan. Peran pemangku kepentingan yang berusaha memberikan yang terbaik bagi perusahaan sebanding dengan kesejahtraan dan keselamatan kerja yang diberikan perusahaan. Standar deviasi 0,21 yang nilainya semakin mengecil dari nilai mean menunjukan data sampel yang semakin homogen.

Indikator tanggung jawab dan transparansi atau disclosure and transparency (DT) menunjukkan nilai minimum 55\%, nilai maximum 100\%. Nilai mean sebesar 83\%menunjukan rata-rata DT perusahaan manufaktur tahun 2011 sampai dengan tahun 2013 pada dalam kategori sangat baik. Hal ini mengindikasikan perusahaan selalu berusaha terbuka dan transparan dalam memberikan informasi material baik secara periodik maupunn insidentil. Standar deviasi 0,27 yang nilainya semakin mengecil dari nilai mean menunjukan data sampel yang semakin homogen.

Indikator pertanggungjawaban dewan atau (BR) menunjukan nilai minimum $33 \%$ dan nilai maximum $100 \%$. Nilai rata-rata sebesar $71,78 \%$ menunjukan BR perusahaan manufaktur tahun 2011 sampai dengan tahun 2013 dalam kategori yang cukup baik. Hal ini mengindikasikan perusahaan berusaha cukup maksimal dalam memonitor kinerja manajerial sehingga dapat mencapai tingkat timbal balik (return) yang memadai bagi pemegang saham. Standar deviasi 0,15 yang nilainya semakin mengecil dari nilai mean menunjukan data sampel yang semakin homogen.

\section{Uji Linearitas}

Uji linieritas dalam penelitian ini menggunakan model curve estimation. Penggunakaan curve estimation karena indikator yang digunakan dalam satu variabel lebih dari satu. Hasil uji linearitas menunjukkan bahwa variabel konstruk dalam penelitian ini berhubungan linier satu sama lain karena memiliki nilai signifikansi tidak lebih dari 0,005.

\section{Evaluasi Outer Model}

Langkah awal evaluasi model dengan PLS dalam penelitian ini adalah evaluasi pada model pengukuran / measurement (outer model). Evaluasi outer model yang pertama yaitu evaluasi konstruk dengan indikator reflektif. Hasil kalkulasi awal algoritma PLS model penelitian ini adalah sebagai berikut :

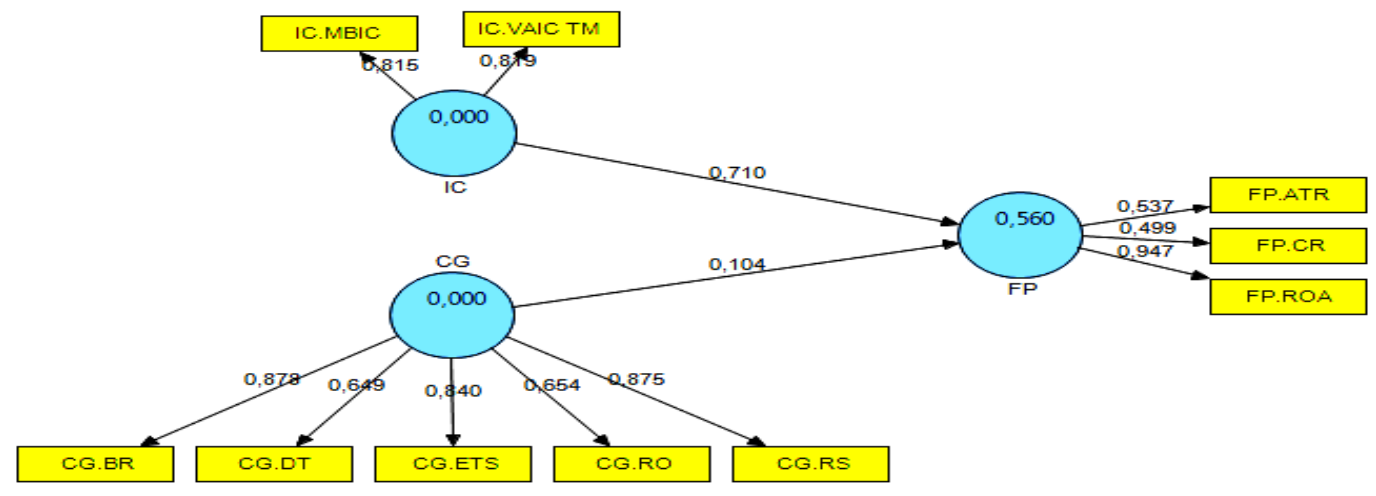

Gambar 1. Hasil Kalkulasi Awal Algoritma PLS

Berdasarkan gambar 1 dapat dilihat loading faktor untuk indikator FP.CR memiliki nilai loading factor di bawah 0,5 sehingga harus di drop dari model agar dapat dilakukan kalkulasi kembali. Setelah indikator FP.CR di drop dari model, dan dilakukan calculate algortihm kembali, berikut hasil kalkulasi akhir algoritma PLS model penelitian ini. 




Gambar 2. Hasil Kalkulasi Akhir Algoritma PLS

Berdasarkan gambar 2, dapat dilihat loading faktor untuk tiga variabel dengan indikator reflektif (1) Loading factor untuk indikator FP.ATR 0,603dan FP.ROA 0,956 sehingga dapat dinyatakan konstruk FP sudah memenuhi uji convergent validity karena loading faktornya $>0,5$, (2) Loading factor untuk indikator IC.MBIC0,830 dan IC.VAICTM 0,803 sehingga dapat dinyatakan konstruk IC sudah memenuhi uji convergent validity karena loading faktornya > 0,5. Dan (3) Loading factor untuk indikator CG.RS 0,874, CG.ETS 0,842, CG.RO0,679, CG.DT 0,623, dan CG.BR0,873 sehingga dapat dinyatakan konstruk FC sudah memenuhi uji convergent validity karena loading faktornya $>0,5$.

Selain uji convergent validity, konstruk dengan indikator reflektif juga perlu diuji reliabilitas model dengan melihat composite reliabilitypada output algoritma PLS, seperti pada tabel 2 berikut ini :
Tabel 2. CompositeReliability

\begin{tabular}{cc}
\hline & $\begin{array}{c}\text { Composite } \\
\text { Reliability }\end{array}$ \\
\hline FP & 0,767755 \\
IC & 0,800330 \\
CG & 0,887710 \\
\hline
\end{tabular}

Tabel 2 menunjukkan bahwa konstruk FP, IC dan CG memiliki composite reliability > 0,7 artinya konstruk FP, IC dan CG dapat dinyatakan reliabel. Selanjutnya konstruk dengan indikator reflektif diuji validitasnya model dengan melihat T-statistik pada outer loadings seperti pada tabel 3.

Dari hasil outer loadings di atas dapat dilihat bahwa seluruh indikator konstruk dalam model valid di mana nilai $\mathrm{T}$ statistic yang dihasilkan $>1,64$. Sehingga semua indikator valid dalam merefleksikan variabel laten yang diukur. 
Dewa Ayu Oki A.R., Akram, Lilik Handajani Jurnal InFestasi Vol.12, No.1, Juni 2016

Tabel 3. Outer loadings (Mean, STDEV, T-Values)

\begin{tabular}{ccccccc}
\hline & $\begin{array}{c}\text { Original } \\
\text { Sample } \\
(\mathrm{O})\end{array}$ & $\begin{array}{c}\text { Sample } \\
\text { Mean (M) }\end{array}$ & $\begin{array}{c}\text { Standard } \\
\text { Deviation } \\
(\text { STDEV) }\end{array}$ & $\begin{array}{c}\text { Standard } \\
\text { Error } \\
(\text { STERR) }\end{array}$ & $\begin{array}{c}\text { T Statistics } \\
(\mid \text { O/STERR })\end{array}$ & Keterangan \\
\hline $\begin{array}{c}\text { CG.BR } \\
\text { <- CG }\end{array}$ & 0,872661 & 0,868128 & 0,025994 & 0,025994 & 33,571886 & Signifikan \\
$\begin{array}{c}\text { CG.DT } \\
<- \text { CG }\end{array}$ & 0,624711 & 0,619841 & 0,078457 & 0,078457 & 7,962462 & Signifikan \\
$\begin{array}{c}\text { CG.ETS } \\
\text { <- CG }\end{array}$ & 0,84235 & 0,834425 & 0,048153 & 0,048153 & 17,493323 & Signifikan \\
$\begin{array}{c}\text { CG.RO } \\
\text { <- CG }\end{array}$ & 0,677409 & 0,678534 & 0,086486 & 0,086486 & 7,832585 & Signifikan \\
$\begin{array}{c}\text { CG.RS } \\
\text { <- CG }\end{array}$ & 0,87424 & 0,867001 & 0,039379 & 0,039379 & 22,200852 & Signifikan \\
$\begin{array}{c}\text { FP.ATR } \\
\text { <- FP }\end{array}$ & 0,591547 & 0,551518 & 0,186605 & 0,186605 & 3,170052 & Signifikan \\
$\begin{array}{c}\text { FP.ROA } \\
\text { <- FP }\end{array}$ & 0,960094 & 0,961483 & 0,020473 & 0,020473 & 46,894919 & Signifikan \\
$\begin{array}{c}\text { IC.MBIC } \\
\text { <- IC }\end{array}$ & 0,831598 & 0,832891 & 0,038477 & 0,038477 & 21,613129 & Signifikan \\
$\begin{array}{c}\text { IC.VAIC } \\
\text { TM <- IC }\end{array}$ & 0,801776 & 0,796145 & 0,051601 & 0,051601 & 15,537972 & Signifikan \\
\hline
\end{tabular}

\section{Evaluasi Inner Model}

Setelah seluruh outer model dievaluasi selanjutnya adalah evaluasi pada inner model sekaligus uji hipotesis model penelitian ini. Evaluasi inner model dan uji hipotesis model penelitian ini adalah sebagai berikut ini. Nilai R Square adalah koefisien determinasi pada konstruk endogen, digunakan untuk melihat kemampuan variabel-variabel eksogen untuk menerangkan variabel endogen. Dapat dilihat dari nilai R-square dari variabel endogen.

Variabel financial perfomance (FP) dapat dijelaskan oleh variabel IC, CG dan FC sebesar 0,582472 atau $58,24 \%$ sementara 41,76 \% diterangkan oleh variabel lain yang tidak diteliti. Konstruk variabel financial perfomance (FP) dapat diterangkan oleh konstruk variabel intellectual capital (IC) dan corporate
Goodness of Fit (GOF) digunakan untuk mengevaluasi model secara keseluruhan dengan rumus yang telah dijelaskan pada bab 3. Dalam Smart PLS index ini tidak sajikan secara langsung sehingga dilakukan perhitungan secara manual. Index GOF 0,6 yang artinya variansi yang dijelaskan oleh konstrukkonstruk dalam model lebih besar dari faktor residual diluar model. Berdasarkan kriteria index GOF maka model dalam penelitian ini masuk dalam kategori kuat, karena index GOF > 0,36.

\section{Uji Hipotesis}

Uji hipotesis dengan melihat estimate for path coefficients, dengan prosedur bootstrapping. Berikut gambar hasil bootsrapping model penelitian ini

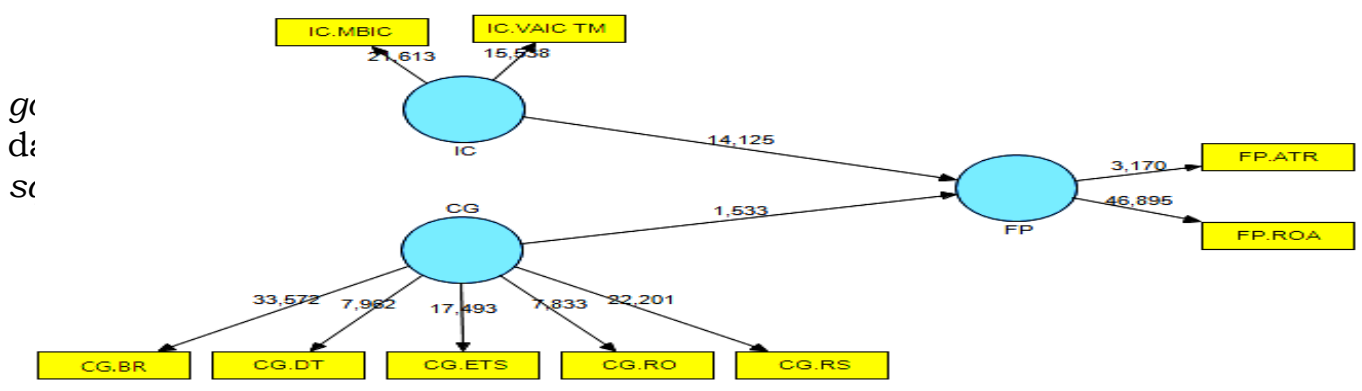




\section{Gambar 3. Hasil Kalkulasi Boosttrapping}

Untuk menguji hipotesis yang diajukan, dapat dilihat dari besarnya nilai t-statistik yang diperoleh. Batas untuk menolak dan menerima hipotesis yang diajukan adalah 1,64 (t-tabel), dimana apabila nilai $\mathrm{t}$-statistik $>(1,64) \mathrm{t}$ - tabel, maka hipotesis akan diterima dan jika sebaliknya akan ditolak. Hasil estimasi t-statistik dapat dilihat pada Tabel 4.6 Result for Path Coeficients berikut :

Tabel 4. Path Coefficients (Mean, STDEV, T-Values

\begin{tabular}{cccccc} 
& $\begin{array}{c}\text { Original } \\
\text { Sample (O) }\end{array}$ & $\begin{array}{c}\text { Sample } \\
\text { Mean (M) }\end{array}$ & $\begin{array}{c}\text { Standard } \\
\text { Deviation } \\
\text { (STDEV) }\end{array}$ & $\begin{array}{c}\text { Standard } \\
\text { Error } \\
\text { (STERR) }\end{array}$ & $\begin{array}{c}\text { T Statistics } \\
(\mid \text { O /STERR |) }\end{array}$ \\
\hline $\begin{array}{c}\text { CG -> } \\
\text { FP }\end{array}$ & 0,10854 & 0,130598 & 0,0708 & 0,0708 & 1,533053 \\
$\begin{array}{c}\text { IC -> } \\
\text { FP }\end{array}$ & 0,72229 & 0,719733 & 0,051137 & 0,051137 & 14,124655 \\
\hline
\end{tabular}

Variabel IC memiliki koefisien parameter 0,72229 dan nilai t statistik $14,124655>1,64$ (t tabel), artinya IC berpengaruh signifikan positif terhadap kinerja keuangan. Semakin besar IC yang dimiliki oleh perusahaan maka kinerja keuangan akan semakin meningkat. Dengan demikian $\mathrm{H}_{1}$ dalam penelitian ini diterima. Variabel CG memiliki koefisien parameter 0,10854 dan nilai $\mathrm{t}$ statistik $1,533053<1,64$ (t tabel), artinya CG tidak berpengaruh signifikan terhadap kinerja keuangan, sehingga $\mathrm{H}_{2}$ dalam penelitian ini ditolak.

\section{Pengaruh IC terhadap Kinerja Keuangan}

Penerimaan Hipotesis $1 \quad\left(\mathrm{H}_{1}\right)$ dalam penelitian ini diterima dan memberikan bukti bahwa IC pada perusahaan manufaktur dapat mempengaruhi kinerja kuangan (IC merupakan determinan kinerja keuangan). Hal ini mengindikasikan perusahaan manufaktur memanfatkan IC secara maksimal untuk meningkatkan kinerja keuangan.

Hasil penelitian ini dapat memberikan bukti bahwa VAICTM dan MBIC merupakan indikator yang dominan dalam merefleksikan IC karena nilai t-statistiknya pada outer loadings diatas 1,64. Hal ini mengindikasikan perusahan telah memberikan perhatian yang optimal terhadap pengembangan VAIC $^{\text {TM }}$ dan MBIC yang dimiliki perusahaan mampu menunjukan adanya IC yang tidak dilaporkan perusahaan. VAIC ${ }^{\mathrm{TM}}$ berhasil menciptakan keunggulan kompetitif yang menunjang perusahaan untuk beradaptasi pada perubahanperubahan yang ada di lingkungan bisnis dan MBIC (market based intellectual capital) yang memiliki kemampuan untuk meningkatkan laba telah berhasil menampilkan IC sebagai sumber daya yang potensial bagi perusahaan.

IC berpengaruh signifikan positif terhadap kinerja keuangan perusahaan manufaktur karena memiliki nilai tstatistik pada path coeficinet diatas 1,64 yaitu $14,124655 . \quad \mathrm{Hal}$ ini mengindikasikan IC merupakan sumber daya perusahaan yang memiliki kemampuan menciptakan nilai tambah bagi perusahaan untuk menggerakan kinerja keuangan. Hasil penelitian ini sejalan dengan penelitian Chen et al.,(2005), Tan et al., (2007), Ullum et al.,(2008), Soetedjo dan Mursida (2008), Gamayuni (2010), Yunita (2012), Fajarini dan Firmansyah (2012), Kumalasari (2013), Prastya (2014) menyimpulkan adanya pengaruh positif IC tehadap kinerja keuangan. Hal ini mengindikasikan pentinganya pemanfaatan IC dengan semaksimal mungkin oleh perusahaan karena berkaitan dengan usaha perusahan untuk meningkatkan kinerja keuangan.

Hasil penelitian ini tidak sejalan dengan hasil penelitian oleh Firer dan 
Wiliams (2003) serta Subagyo dan Lahagu (2012) yang tidak menemukan adanya pengaruh IC yang signifikan terhadap kinerja keuangan. Hal ini mengindikasikan kurangnya keyakinan perusahaan terhadap potensi IC dan keseriusan perusahaan terhadap pengembangan dan pengelolan IC akan menyebabkan lemahnya kemampuan IC dalam mempengaruhi kinerja keuangan.

IC yang berpengaruh signifikan postif terhadap kinerja keuangan, mengindikasikan perusahaan mampu menghasilkan nilai tambah melalui VAIC $^{\mathrm{TM}}$ dan meningkatkan nilai intangible asset dengan metode MBIC. VAIC ${ }^{\mathrm{TM}}$ merupakan jumlah dari tiga jenis input perusahaan yaitu modal manusia, modal struktural fisik dan financial yang terdiri dari human capital efficiency, structural capital efficiency dan capital employed efficiency yang dimanfaatkan secara efisien oleh perusahaan sehingga menghasilkan VAICTM yang bernilai tinggi. Perusahaan memanfaatkan VAIC ${ }^{\text {TM }}$ untuk menciptakan karakter unik yang dijadikan sebagai keunggulan kompetitif perusahan yang tidak dimiliki perusahaan lain. Pengukuran IC dengan MBIC mengggunakan selisih nilai pasar dengan nilai buku, yaitu dimana semakin besar nilai pasar terhadap nilai buku akan menunjukan tinginya jumlah IC yang dinillai oleh para investor atau shareholder. Tingginya penilaian IC yang diberikan oleh investor mencerminkan keyakinan investor terhadap prospek perusahaan kedepanya yang akan dijadikan bahan pertimbangan dalam keputusan berinvestasi. Dengan demikian pengelolan IC yang optimal dapat dilakukan perusahaan dengan adanya keseriusan perusahaan untuk menghasilkan VAIC $^{\text {TM }}$ yang tinggi dan perhatian terhadap MBIC yang dimiliki karena hal tersebut akan berpengaruh terhadap kinerja keuangan.

\section{Pengaruh Corporate Governance terhadap Kinerja Keuangan}

Hipotesis ke-2 $\left(\mathrm{H}_{2}\right)$ dalam penelitian ini di tolak dan memberikan bukti bahwa corporate governance tidak mempengaruhi kinerja keuangan perusahaan manufaktur (corporate governance bukan determinan kinerja keuangan). Hasil penelitian memberikan bukti bahwa RS, ETS, RO, DT dan BR merupakan indikator yang dominan dalam merefleksikan CG karena nilai tstatistiknya pada outer loadings diatas 1,64. Hal ini mengindikasikan prinsip OECD (2004) yang memuat mengenai hak pemegang saham, keseteraan perlakuan terhadap pemegang saham, peran stakeholder dalam tata kelola perusahaan dan pengungkapan transaparansi telah menjadi kebutuhan bagi perushaan untuk meciptakan corporate governance yang lebih baik

CG tidak berpengaruh signifikan terhadap kinerja keuangan perusahaan manufaktur karena memiliki nilai tstatistik pada path coefficients dibawah 1,64 yaitu 0,688905 . Hasil penelitian ini sejalan dengan penelitian yang dilakukan oleh Supatmi (2007), Windah dan Andono (2013) serta Utari dan Fachurzzman (2013) mengungkapkan bahwa corporate governance tidak berpengaruh terhadap kinerja keuangan. $\mathrm{Hal}$ ini mengindikasikan rendahnya tingkat keselarasan antara pelaksanaan praktik corporate governance dengan penilaian akan praktik corporate governance yang baik sehingga belum berhasil meningkatkan kinerja keuangan. Hasil penelitian dan pernyataan tersebut berdasarkan pada statistik deskriptif dalam tabel 4.2. Statistik deskriptif menunjukan nilai mean pada prinsip hak pemegang sahan dan kesetaraan perlakuan pemegang saham yang tergolong rendah, dibandingkan tiga prinsip lainya yaitu peran pemangku kepentingan dalam corporate governance, transparansi dan tanggung jawab dewan.

Hasil penelitian ini tidak sejalan dengan penelitian Prastya (2014), Klapper dan Love (2002), Cornet et al.,(2006), Arifani (2013) yang menemukan adanya pengaruh corporate governance terhadap kinerja keuangan. Hal ini mengindikasikan adanya keselarasan yang baik antara pelaksanaan dan indikator yang digunakan dalam mengukur praktik corporate governance yang baik. Tingkat keselaran yang tinggi mendukung kekuatan praktik corporate governance dalam untuk berhasil meningkatkan kinerja keuangan.

Corporate governance yang tidak berpengaruh signifikan terhadap kinerja 
keuangan, mengindikasikan praktik corporate governance yang merujuk pada prinsip OECD (2004) masih di dominasi pada prinsip yang sudah menjadi ketentuan yang ditetapkan oleh Bapepam yaitu keterbukaan dan transparansi serta tanggung jawab dewan. Dari tiga prinip yang belum ditetapkan Bapepam hanya peran stakeholder dalam corporate governance yang mampu menyimbangi dua prinsip yang mendominasi tersebut, sedangakan dua prinsip OECD (2004) yaitu hak pemegang sahan dan kesetaraan terhadap perlakuan terhadap pemegang saham masih rendah.

\section{PENUTUP}

\section{Simpulan}

Hasil penelitan ini menunjukkan bahwa IC berpengaruh signifikan postif terhadap kinerja keuangan, sehingga IC merupakan determinan kinerja keuangan. Hal ini mengindikasikan semakin tinggi IC yang dimiliki perusahaan maka kinerja keuangan akan semakin tinggi. Perusahaan yang memiliki IC yang tinggi harus didukung dengan keseriusan perusahaan untuk menghasilkan nilai tambah dengan metode VAIC ${ }^{\mathrm{TM}}$ yang tinggi dan menaikan nilai intangible asset dengan metode MBIC.

Corporate governance tidak berpengaruh signifikan terhadap kinerja keuangan sehingga corporate governance bukan merupakan determinan kinerja keuangan. Hal ini mengindikasikan rendahnya tingkat keselarasan pelaksanaan praktik corporate governance terhadap keseluruhan prinsip OECD (2004). Praktik corporate governance yang merujuk pada prinsip OECD (2004) masih di dominasi oleh peran stakeholder dalam corporate governance, keterbukaan dan transparansi serta tanggungjawab dewan. Kedepanya perusahaan harus lebih meningkatkan perhatian dan kepatuhan terhadap prinsip hak pemegang saham dan kesetaraan perlakukan terhadap pemegang saham.

\section{Implikasi Hasil Penelitian.}

Hasil penelitian ini secara teoritis dapat memberikan kontribusi pengetahuan karena mampu mendukung resource based view theory dan signaling theory. Hasil penelitian ini sejalan dengan resource based theory, yang menjelaskan intellectual capital sebagai intanggible resourcedapat menciptakan keunggulan kompetitif berkelanjutan (sustained competitive advantages) untung mendukung perusahaan agar dapat terus bersaing dan berkembang dalam dunia bisnis yang mengarahkan perusahaan kepada perbaikan kinerja keuangan. Hal yang berbeda ditunjukan oleh agency theory yang menjelaskan praktik corporate governance yang dapat berperan efektif untuk mengatur dengan jelas pendistribusian hak dan kewajiban dewan dan pemegang saham, akan menarik kepercayaan investor sehingga tertarik untuk berinvestasi yang akan menunjang keberhasilan mencapai tujuan perusahaan yaitu meningkatkan kinerja keuangan. Hasil penelitian ini tidak sejalan dengan agency theory tersebut, karenaperusahaan belum mampu melaksanakan keseluruhan prinsip OECD (2004) yang mendukung agar praktik corporate governance dapat berperan efektif.

Hasil penelitian ini secara praktis dapat memberikan informasi bagi manajemen mengenai pentingnya intellectual capital dan praktik corporate governance yang patuh pada prinsip OECD (2004). Selanjutnya hasil penelitian ini dapat memberikan gambaran bagi investor dan stakeholderdalam menganailisis kinerja keuangan dan kelayakan sebuah perusahaan untuk menjadi target investasi, yaitu dengan tidak hanya melihat dari tangible asset yang dimiliki perusahaan tapi juga intanggible asset perusahaan seperti intellectual capital dan juga informasi non keuangan seperti karakteristik perusahaan. Terakhir hasil penelitian ini diharapkan dapat dijadikan literatur mengenai intellectual capital, karakteristik perusahaan, corporate governance dan kinerja keuangan bagi para akademisi dan penelitian selanjutnya.

Hasil penelitian ini secara kebijakan dapat memberikan masukan bagi para pembuat kebijakan baik manajemen perusahaan, dewan standar akuntansi keuangan maupun pemerintah. Saran atau masukan 
tersebut berkaitan dalam regulasiregulasi yang diterapkan bagi perusahaan maupun lembaga keuangan di Indonesia berkaitan dengan pengungkapan intellectual capital dan penerapan prinsip OECD (2004) pada praktik corporate governance. Pemerintah sebagai pembuat kebijakan disarankan dapat menentukan regulasi yang tepat dan manajemen serta dewan akuntansi diharapakan dapat mematuhi regulasi yang telah ditetapkan mengenai intellectual capital dan corporate governance. Saran tersebut atas dasar hasil penelitian menunjukan persyaratan PSAK 19 revisi 2010 masih sulit dipenuhi perusahaan sehingga menjadikan sampai saat ini IC belum dapat dilaporkan sebagai intangible asset dalam laporan keuangan, dan penerapan keseluruhan prinsip-prinsip corporate governance sesuai dengan OECD (2004) yang dilaporkan dalam annual report menunjukan perkembangan dengan tingkat yang masih rendah.

\section{Keterbatasan dan Saran Penelitian Mendatang.}

Beberapa keterbatasan dalam penelitian ini dapat memberikan arahan bagi penelitian yang akan datang. Pertama, penelitian ini hanya menggunakan data 3 tahun dan subjek hanya pada perusahaan manufaktur.Agar menghasilkan hasil penelitian yang optimal, penelitian selanjutnya dapat menggunakan data penelitian lebih dari 3 tahun dan menambah subjek penelitian selain pada perusahaan manufaktur seperti pada perusahaan perbankan. Subjek penelitian yang berbeda tentunya memiliki perbedaaan pada karakter IC, kepatuhan pada keseluruhan prinsip OECD (2004) dan karakteristik perusahaan.

Kedua, IC dalam penelitian ini hanya menggunakan 2 indikator yaitu metode VAICTM dan MBIC. Penelitian selanjutnya dapat menambahkan indikator lain seperti model The EVA dan MVA sebagaimana dikemukakan oleh Bontis et. al, (1999). Terakhir, mengingat terus dilakukanya pengembangan penilaian praktik corporate governance yang baik pada prinsip OECD, penelitian selanjutnya dapat menggunakan indikator prinsip OECD (2008) yang diutamakan

multinasional.

bagi

perusahaan

\section{DAFTAR PUSTAKA}

Arifani, Rizky. 2012. Pengaruh Good Corporate Governance Terhadap Kinerja Keuangan Perusahaan. Universitas Brawijaya.

Badan Pengawasan Pasar Modal Dan Lembaga

(Bapepam).2006. Studi Keuangan Penerapan Prinsip-prinsip OECD 2004 dalam Peraturan Bapepam mengenai Corporate Governance.

Barney, J. 1991. Firm Resources and Sustained Competitive Advantage. Journal of Management 17(1): 99-120.

Boediono, Gideon Setyo Budiwitjaksono. 2005. Kualitas Laba: Studi Pengaruh Mekanisme

Corporate Governance dan Dampak Manajemen Laba Dengan Menggunakan Analisis Jalur. Simposium Nasional Akuntansi VIII. Solo.

Bontis, N. 1998. "Intellectual Capital: an Exploratory Study that DevelopsMeasures and Models. "Management Decision. Vol. 36 No. 2, 63- 76. 2004. National Intellectual Capital Index; A United Nations

Initiative For The Arab Regions. Journal Of Intellectual Capital.

Brealey, et al.2007. Dasar-dasar Manajemen Keuangan Perusahaan. Jilid 2.Edisi Kelima. Jakarta: Erlangga.

Chen, M.C., S.J. Cheng, Y. Hwang. 2005. "An Empirical Investigation of the Relationship between Intellectual Capital and Firms' Market Value and Financial Performance". Journal of Intellectual Capital. Vol. 6 NO. 2. pp. 159-176.

Edvinsion, S. Malone. 1997. Intellectual Capital. Realiziy Your Company's True Value By Finding It's Hidden Brain Power. New York Harper. Publishing USA.

Fajarini, Indah dan Riza Firmansyah. 2012. Pengaruh Intellectual Capital 
Terhadap Kinerja Keuangan (Studi Empiris Perusahaan LQ 45). Jurnal Dinamikan Akuntansi.

Firer, S. and S.M. Williams. 2003. "Intellectual Capital and Ttraditional Measures of Corporate Performance". Journal of Intellectual Capital. Vol. 4 No. 3. pp. 348-360.

Gamayuni, Rindu Rika. 2010. Pengaruh Intangible Asset, Kebijakan Keuangan, dan Kinerja Keuangan Terhadap Nilai Perusahaan. Universitas Lampung.

Jensen, M., and W. Meckling 1976. Theory of the Firm : Managerial Behavior, Agency, and Ownership Structure. Journal of Financial Economics,(1976), 305-360.

Klapper, Leora F. and I. Love. 2002. Corporate Governance, Investor Protection, and Performance in Emerging Markets. World Bank Working Paper. http:// ssrn.com.

Kumalasari dan Astika. 2013. Pengaruh Modal Intellektual terhadap Kinerja Keuangan di Bursa Efek Indonesia. Fakultas Ekonomi Universitas Udayana Bali.

Moloi, S.T.M. 2008. Assestment of Corporate Governance Reporting in the Annual.

Munawir. 2002. Analisis Laporan Keuangan, Edisi Keempat. Yogyakarta.

Nakamura, L. 1999. "Intangibles: What Put the New in The New Economy?. Federal Reserve Bank of Philadelphia Business Review. (July/August): 16.

Organisation for Economic Cooperation and Development (OECD). 2004. Principles of Corporate Governance 2004.

Prastya, Ony Maretha. 2014. Pengaruh Modal Intellektual dan Tata Kelola Perusahaan terhadap Kinerja Keuangan. Universitas Negeri Surabaya.

Pulic, A. 1998. Measuring the Performance of Intellectual Potential in Knowledge Economy. Available from: www.vaic-on.net.

Sharpe, William F.1997. Investasi. Edisi Bahasa Indonesia Jilid 1 \& 2. Jakarta: Renhallindo.
Soetedjo dan Mursida. 2008. Pengaruh Intellectual Capital terhadap Kinerja Keuangan Pad Perusahaan Perbankan. Fakultas Ekonomi dan Bisnis Universitas Airlangga Surabaya.

Song, H.S. (2005). Capital Structure Determinants: An Empirical Study of Swedish Companies. Presented at Conference "Innovation Entrepreneurship and Growth". Stockholm, November 18-20.

Subagyo dan Sarah Harazaki Lahagu. 2012. Pengaruh Intellectual Capitalt terhadap Kinerja Keuangan Perbankan. Fakultas Ekonomi Kristen Krida Wacana.

Supatmi.2007. Corporate Governance dan Kinerja Keuangan. Fakultas Ekonomi Universitas Kristen Satya Kencana.

Susilawati, Chirstine Dwi Karya dan Felix Hendra Soetjipta. 2013. Peranan Audit Intern Dalam Penerapan Good Corporate Governance Yang Efektif. Universitas Kristen Maranatha

Tan, H.P., D. Plowman, P. Hancock. 2007. "Intellectual Capital and Financial Returns of Companies. Journal of Intellectual Capital. Vol. 8 No. 1. pp. 76-95.

Ullum et al. 2008. Intellectual Capital dan Kinerja Keuangan Perusahaan: Suatu Analisis dengan Pendekatan Partial Least Squares. SNA XI Pontianak.

Utari, Ayu Dwi dan Fachruzzaman.2013. Analisis Pengaruh Mekanisme Corporate Governance, Firm Size, dan Growth Oppurtunity Terhadap Kinerja Perusahaan BUMN Yang Terdaftar Di BEI Periode 20072012. Universitas Bina Nusantara.

Van Horne, James C. And John. M Wachowicz.2005. Prinsip-prinsip Manajemen Keuangan Buku Satu. Edisi Kedua Belas. Jakarta Salemba Empat.

Wernerfelt, B. 1984. A Resourced-Based View of The Firm. Strategic Management Journal. Vol.5: 171-180.

Windah, Gabriela Cynthia dan Fidelis Arastyo Andono. 2013. Pengaruh Penerapan Corporate Governance Terhadap Kinerja Keuangan. Universitas Surabaya. 
Yunita, Novelina.2013. Pengaruh Modal Intellektual terhadap Kinerja Keuangan dan Nilai Pasar. Jurusan Akuntansi, Fakultas Ekonomi, Universitas Negeri Semarang. 